\title{
Treatment of pityriasis versicolor with topical application of essential oil of Cymbopogon citratus (DC) Stapf - therapeutic pilot study
}

\author{
Tratamento de pitiríase versicolor com aplicação tópica do óleo essencial de \\ Cymbopogon citratus (DC) Stapf - estudo terapêutico piloto
}

Egberto Santos Carmo ${ }^{1}$

Neuza Maria Cavalcante ${ }^{3}$

Edeltrudes de Oliveira Lima ${ }^{5}$
Fillipe de Oliveira Pereira ${ }^{2}$

Carla Wanderley Gayoso ${ }^{4}$

\begin{abstract}
BACKGROUND: Pityriasis versicolor is a fungal infection caused by Malassezia spp. that has frequent relapses. OвJеCTIVES: The main objective of this research was to perform phase I and II clinical studies, using formulations containing essential oil of Cymbopogon citratus in patients with pityriasis versicolor. METHODS: Phase I study included twenty volunteers to ascertain the safety of the formulations. In phase II, 47 volunteers randomly received essential oil formulations at $1.25 \mu \mathrm{L} / \mathrm{mL}$ concentration, for forty days. The shampoo should be applied three times a week and the cream twice a day. A control group in phase II, consisting of 29 volunteers, received the same formulations but with $2 \%$ ketoconazole as the active ingredient. ResulTs: No significant adverse events were observed in volunteers during Phase I. In Phase II, 30 (63.83\%) volunteers using essential oil and $18(62.07 \%)$ using ketoconazole remained until the end of the study. We observed a predominance of lesions in disseminated form, with M. sympodialis detected as the predominant agent identified in cultures. After 40 days of treatment, the rate of mycological cure was $60 \%(\mathrm{p}<0.05)$ for the group treated with essential oil of $\mathrm{C}$. citratus and over $80 \%(\mathrm{p}<0.05)$ for the group treated with ketoconazole formulations. ConCLUSIONs: Notwithstanding the safety and antifungal effects observed in this study after application of formulations containing the essential oil of C. citratus, further studies with larger populations should be performed to confirm the actual potential of these formulations in the treatment of patients with Pityriasis versicolor.
\end{abstract}

Keywords: Antifungal agents; Infection; Malassezia; Mycoses; Tinea versicolor

Resumo: FundAmEnTOS: Pitiríase versicolor é uma micose causada pela Malassezia spp., e que apresenta frequentes recidivas. OвJETIVOS: Este trabalho objetivou realizar estudos clínicos de fase I e II, para essa patologia, com óleo essencial de Cymbopogon citratus. MÉTODOs: Na fase I, participaram vinte voluntários para averiguar a segurança das formulações. Na fase II, 47 voluntários receberam as formulações do óleo essencial a 1,25 $\mu \mathrm{L} / \mathrm{mL}$, as quais deveriam ser utilizadas por quarenta dias, sendo o xampu três vezes por semana e o creme duas vezes ao dia. Um grupo controle na fase II, constituído por 29 voluntários recebeu as mesmas formulações, com cetoconazol a $2 \%$. RESULTADOS: Verificada a segurança das formulações com a finalização da fase I, onde nenhuma reação adversa significativa foi observada nos indivíduos sadios, conduziu-se a fase II. Nesta segunda fase, 30 $(63,83 \%)$ voluntários utilizando óleo essencial e 18 (62,07\%) cetoconazol permaneceram até o final do estudo. Observaram-se nos pacientes com pitiríase versicolor predomínio de lesões na forma disseminada e M. sympodialis foi o agente predominante identificado em cultura. Após 40 dias de tratamento, obteve-se um percentual de cura micológica de $60 \%(\mathrm{p}<0,05)$ para o grupo tratado com óleo essencial de C. citratus e superior a $80 \%(p$ $<0,05)$ para o grupo tratado com cetoconazol. ConCLUsõEs: Apesar da segurança e efeito antifúngico observados após aplicação das formulações contendo óleo essencial de C. citratus, outros estudos com maior número de portadores de pitiríase versicolor precisam ser realizados para confirmar o real potencial destas formulações.

Palavras-chave: Antifúngicos; Infecção; Malassezia; Micoses; Tinha versicolor

Received on 07.04.2012.

Approved by the Advisory Board and accepted for publication on 28.07.2012.

* Research performed at the Hospital Universitário Lauro Wanderley at Federal University of Paraíba (UFPB) - João Pessoa (PB), Brazil.

Conflict of interest: None

Financial funding: None

PHD - Professor of Clinical Microbiology, Federal University of Campina Grande (UFCG) - Cuité (PB), Brazil

PHD - Professor of Biochemistry, Federal University of Campina Grande (UFCG) - Cuité (PB), Brazil.

MSc - Pharmaceutical Laboratory of Mycology, University Hospital Lauro Wanderley, Federal University of Paraiba (UFPB) - João Pessoa (PB), Brazil.

PHD - Professor of Dermatology, Federal University of Paraiba (UFPB) - João Pessoa (PB), Brazil.

PHD - Professor of Clinical Mycology, Federal University of Paraiba (UFPB) - João Pessoa (PB), Brazil. 


\section{INTRODUCTION}

Pityriasis versicolor or Tinea versicolor is a superficial mycosis caused by yeasts of the genus Malassezia spp., prevalent in tropical countries and especially affecting individuals with diminished immunity status. It is a pigmentation disorder clinically characterized by the presence of macular lesions, initially perifollicular with fine scaling, variable color spanning from white to brown and occasionally becoming erythematous. ${ }^{1-3}$

The treatment of this fungal infection varies depending on the severity of the lesions, usually including topical or systemic imidazole derivatives. However, the emergence of fungal strains resistant to the available antifungal agents on the market and the frequent bouts of recurrence of pityriasis versicolor in patients, demonstrate that the development of new antifungal agents is a necessary strategy to overcome problems encountered in treating this disease. ${ }^{4.5}$

Several studies have reported the antimicrobial activity of the essential oil of Cymbopogon citratus (DC) Stapf against different Gram positive and Gram negative pathogenic bacteria, yeasts and filamentous fungi. ${ }^{6-8}$ Some authors attribute the oil's antimicrobial properties to the presence of citral in its composition. ${ }^{9}$ Investigations on this oil's activity over the genus Malassezia found that the growth of $100 \%$ strains was inhibited at $1.25 \mu \mathrm{L} / \mathrm{mL}$ concentration by a mechanism which certainly involved the essential oil-ergosterol interaction with the fungal membrane. ${ }^{10}$

In addition to the proven antifungal activity of the essential oil of Cymbopogon citratus, other preclinical in vitro and in vivo studies on toxicity confirmed the safety of this product at low concentations. ${ }^{10-14}$

Based on the aforementioned preclinical studies that confirmed the antifungal activity and safety of this oil, we conducted phase I and II clinical studies with two pharmaceutical formulations containing essential oil of $C$. citratus in the forms of shampoo and cream.

\section{MATERIAL AND METHODS Population}

The study included 96 volunteers who attended the dermatology outpatient clinic in the Lauro Wanderley University Hospital at the Federal University of Paraiba between January 2010 and January 2011. Of this total, 20 volunteers participated in the clinical phase I study and 76 participated in the clinical phase II study.

At the end of Phase I, designed to assess the safety of the shampoo and cream formulations containing essential oil of $C$. citratus, a randomized, comparative phase II study with patients clinically diagnosed with Tinea versicolor was initiated in the afore- mentioned outpatient clinic.

Mycological diagnosis of individuals with pityriasis versicolor was confirmed by direct examination with addition of potassium hydroxide $(\mathrm{KOH})$ at 20\% and permanent Quink Ink (Parker) at 2:1 and culture in Mycosel Agar supplemented with ox bile and olive oil. ${ }^{15-16}$ For identification of Malassezia species we followed the protocol proposed by Erchiga, Palomo and Moyano (2008). Pregnant women, immunosuppressed patients or those using antifungal drugs in the last 30 days were excluded from the survey.

\section{Experimental Protocol}

Patients were instructed to use both formulations: a shampoo and a cream containing the essential oil of C. citratus at $1.25 \mu \mathrm{L} / \mathrm{mL}$ concentration. The shampoo should be applied three times a week and the cream twice a day, both for forty days. Patients were instructed to apply the shampoo on the scalp in the morning and evening after bathing, leaving it to act for five minutes before rinsing and applying the cream at the lesions sites.

In Phase II there was a control group, comprised of 29 volunteers who used the same formulations, but containing $2 \%$ ketoconazole as the active constituent, following the same posology and treatment time frame.

At the end of the 40-day period, patients returned to the dermatology clinic and mycology laboratory at the hospital for evaluation of therapeutic response by direct examination and culture of lesions. Patients who agreed to participate in the study signed an informed consent form, as provided in the Regulatory Guidelines and Standards for Research involving human beings, Resolutions 196/96 and 251/97 National Health Council. This research was approved by the Ethics Committee in Human Research of the CCS/UFPB, protocol No. 0037.

\section{Safety and tolerability}

In both phases groups were evaluated regarding local and systemic toxicological manifestations, especially: stinging, swelling, redness, itching or other adverse reactions to any of the formulations.

\section{Statistical Analyses}

Nominal variables such as: sex, itching, skin color, location, color and type of lesion, and Malassezia species were analyzed using the chi-square test, while the continuous variable "age" was analyzed by unpaired t-test (student). To examine the efficacy of the two treated groups (before and after treatment) and compare the healing power of the products (i.e the proportion of patients with mycological cure) we 
used the Fischer test. Tests were performed using GraphPad Prism( 5.00 (GraphPad Software, San Diego California, USA). Differences were considered statistically significant when $p<0.05$.

\section{RESULTS}

\section{Phase I}

The average age of the 20 volunteers who participated in phase I was 25-37 years and 11 (55\%) of them were males. The volunteers showed good acceptance of the formulations and reported no adverse reactions while using them or afterwards. A volunteer $(5 \%)$ when asked about possible symptoms reported a burning sensation in the scalp on the first day of using the shampoo containing essential oil of $C$. citratus.

\section{Phase II}

After the safety of formulations was verified in phase I, we proceeded with phase II. At this time, thirty volunteers that used products containing essential oil of C. citratus and eighteen using $2 \%$ ketoconazole formulations completed the treatment, reaching a $36.17 \%$ non-adherence rate to the first group and $37.93 \%$ for the second. The reasons for failure in the assessment protocol were several: lack of trust in the treatment; fail to return to the service of dermatology or mycology laboratory and patients not found for follow-up.

No statistically significant difference was observed for demographic data of patients evaluated in phase II (Table 1). The species M. sympodialis was the predominant pathogen identified by culture, regardless of the treated group.

After the treatment period, there was a statistically significant reduction in the number of patients with pityriasis versicolor in both groups (Graph 1). Although data on mycological cure have pointed differences in results between groups treated with oil and ketoconazole, both groups showed relevant therapeutic response confirmed respectively by mycological cure equal or superior to $60 \%$ (Graph 2).

\section{Safety and tolerability}

From the standpoint of safety and tolerability, a voluntary group with $2 \%$ ketoconazole reported headache during use of this formulation, which did not discouraged him from continuing treatment and returning to the dermatology service for reassessment.

\section{DISCUSSION}

The formulations were well tolerated by the group on phase I. However a volunteer $(5 \%)$ cited a burning sensation on the scalp on the first day of
TABLE 1: Clinical characteristics of patients

\begin{tabular}{|c|c|c|}
\hline Patients & Essential oil $(n=30)$ & Ketoconazole $(\mathrm{n}=18$ \\
\hline Age (mean, [range]) & $14-65$ (32.8 years) & $13-56$ (33.5 years) \\
\hline Gender $(\mathrm{M} / \mathrm{F})$ & $10(33.3 \%) / 20(66.7 \%)$ & $10(55.5 \%) / 8(44.4 \%)$ \\
\hline \multicolumn{3}{|l|}{ Skin color } \\
\hline White & $16(53.3 \%)$ & $6(33.3 \%)$ \\
\hline Brown & $12(40.0 \%)$ & $6(33.3 \%)$ \\
\hline Black & $2(6.7 \%)$ & $6(33.3 \%)$ \\
\hline \multicolumn{3}{|l|}{ Site of the lesion } \\
\hline Face & $1(3.3 \%)$ & - \\
\hline Front torso & $4(13.3 \%)$ & $1(5.5 \%)$ \\
\hline Back torso & $4(13.3 \%)$ & $3(16.7 \%)$ \\
\hline Upper limbs & $7(23.3 \%)$ & $4(22 . \%)$ \\
\hline Lower limbs & $1(3.3 \%)$ & $1(5.5 \%)$ \\
\hline Disseminated & $13(43.4 \%)$ & $9(50 \%)$ \\
\hline Itch & $12(40.0 \%)$ & $8(44.4 \%)$ \\
\hline \multicolumn{3}{|c|}{ Color of the lesion } \\
\hline Hypochromic & $25(83.3 \%)$ & $14(77.8 \%)$ \\
\hline Hyperchromic & $4(13.3 \%)$ & $3(16.7 \%)$ \\
\hline Erythematous & $1(3.3 \%)$ & $1(5.5 \%)$ \\
\hline \multicolumn{3}{|l|}{ Type of lesion } \\
\hline Pityrosporum & $6(20.0 \%)$ & $3(16.7 \%)$ \\
\hline Plates & $23(76.7 \%)$ & $15(83.3 \%)$ \\
\hline Both & $1(3.3 \%)$ & - \\
\hline \multicolumn{3}{|c|}{ Malassezia species } \\
\hline M. sympodialis & $10(33.3 \%)$ & $6(33.3 \%)$ \\
\hline M. furfur & $8(26.7 \%)$ & $2(11.1 \%)$ \\
\hline M. obtusa & $1(3.3 \%)$ & - \\
\hline M. globosa & - & $1(5.5 \%)$ \\
\hline M. sloofiae & - & $1(5.5 \%)$ \\
\hline Malassezia spp & $11(36.7 \%)$ & $8(44.4 \%)$ \\
\hline
\end{tabular}

- : Not detected

shampoo application. It might not be related to the formulation containing the essential oil of $C$. citratus itself, but to other variables such as the manner it was applied to the scalp.

The demographic data in this study are in agreement with several other studies in Brazil and worldwide. Pityriasis versicolor is a cosmopolitan disease that affects infants to elders, mostly aged between 15 and 30 years. ${ }^{17-18}$ Patients with pityriasis versicolor usually have multiple lesions on the trunk, especially on the back, interspersed with normal skin. The neck and proximal upper extremities are also frequently affected. On the face, lesions are more common in children than in adults. ${ }^{1,18}$ The following frequencies of lesions were observed through a study performed in Manaus (Brazil): widespread (31.50\%), trunk $(20.65 \%)$, upper limbs $(13.75 \%)$, lower limbs $(9.50 \%)$, face $(8.85 \%) .{ }^{19}$ 


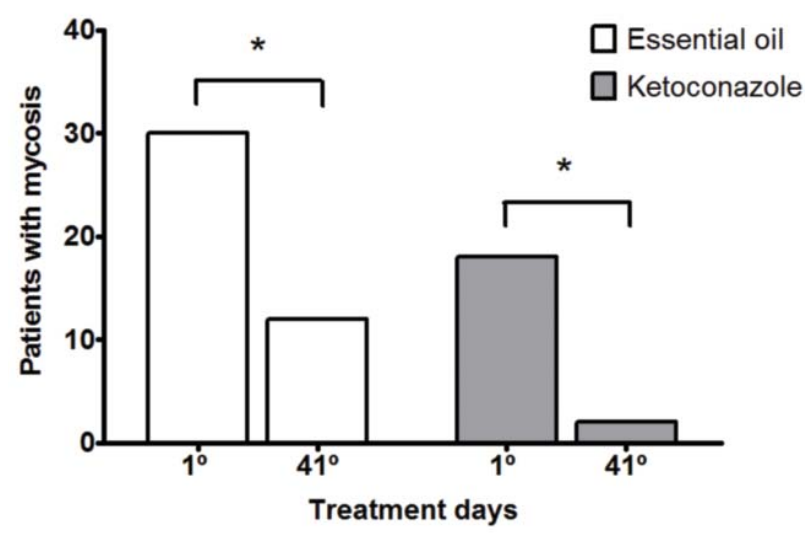

GRAPH 1: Patients with mycosis before (day 1) and after treatment (41 days) with cream and shampoo with essential oil of C. citratus or Ketoconazole * $\mathrm{p}<0.05$ (Fischer's test)

Regarding the etiologic agent, this study showed a prevalence of $M$. sympodialias and $M$. furfur. These agents were among the most commonly isolated in other studies conducted in Goiania (Brazil) and countries like Spain and Indonesia. ${ }^{20-22}$

The adherence was not a limiting factor for this research, since better results could have been perceived if many patients had not abandoned the treatment. Other phase II clinical studies for treatment of fungal infections, diabetes mellitus and fibromyalgia have observed similar adherence rates, ranging between $26-50 \% .^{23-25}$

The mycological cure rate for patients treated with essential oil of $C$. citratus, reaffirms the antifungal potential of this oil on Malassezia yeasts observed in preclinical trials, as well as the safety of formulations in the applied concentration $(1.25 \mu \mathrm{L} / \mathrm{mL})$. However, there was a discrepancy in percentage of the etiological agent's sensitivity between in vitro and in vivo studies, a fact previously observed in similar studies. ${ }^{26-27}$

Research on medicinal plants, especially on essential oils, are promising once such substances have markedly less side effects, low cost and increased security for population, when compared with antifungal agents available in the market, as the ketoconazole and amphotericin B..$^{6,28-29}$

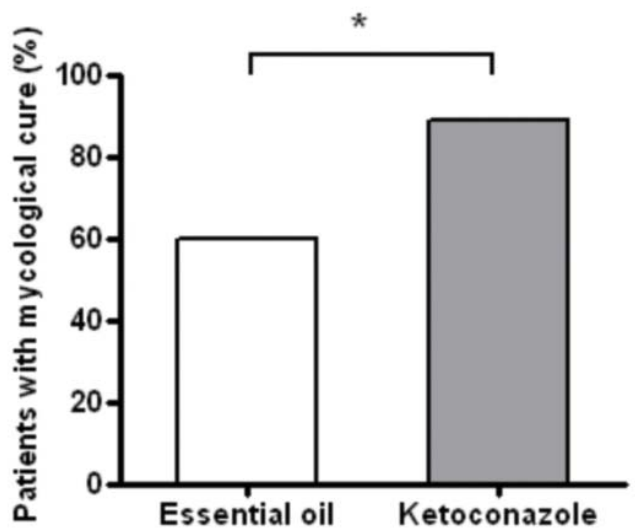

GRAPH 2: Percentage of patients with mycological cure after treatment with cream and shampoo containing essential oil of C. citratus or ketoconazole. ${ }^{*} \mathrm{p}<0.05$ (Fischer's test)

The products containing the essential oil of $C$. citratus used in this study, certainly by the low percentage in the formulation, showed an interesting cost/benefit, since their values were compatible with the formulations containing ketoconazole.

\section{CONCLUSION}

Results of this study indicate good prospects for clinical application of essential oil of $C$. citratus for treatment of Tinea versicolor, due to security and biological effects observed in vivo by mycological cure the group treated with the essential oil of C. citratus. However, it is interesting to conduct further studies with a large number of patients with pityriasis versicolor in order to verify the actual potential observed in this study.

\section{ACKNOWLEDGEMENTS}

We thank all the patients who voluntarily participated in this research. 


\section{REFERENCES}

1. Oliveira JR, Mazocco VT, Steiner D. Pityriasis versicolor. An Bras Dermatol. 2002; 77: 611-8.

2. Erchiga VC, Palomo MC, Moyano, EG. Diagnóstico de laboratorio de las leveduras del género Malassezia. Piel. 2008;23:570-6.

3. Framil VMS, Melhem MSC, Szeszs MW, Corneta ES, Zaitz C. Pityriasis versicolor circinata: isolation of Malassezia sympodialis - Case report. An Bras Dermatol. 2010; 85:227-8.

4. Odds FC, Brown AJP, Gow NAR. Antifungal agents: mechanisms of acion. Trends Microbiol. 2003;11:272-9.

5. Barberán J, Mensa J, Fariñas C, Llinares P, Serrano R, Ménendez R, et al. Recommendations of antifungal treatment in patients with low grade inmunosuppression. Rev Esp Quimioter. 2008;21:127-42.

6. Cimanga K, Kambu K, Tona L, Apers S, De Bruyne T, Hermans N, et al. Correlation between chemical composition and antibacterial activity of essential oils of some aromatic medicinal plants growing in the Democratic Republic of Congo. J Ethanopharmacol. 2002;79:213-20.

7. Irkin R, Korukluoglu M. Effectiveness of Cymbopogon citratus L. essential oil to inhibit the growth of some filamentous fungi and yeasts. J Med Food. 2009;12:193-7.

8. Naik MI, Fomda BA, Jaykumar E, Bhat JA. Antibacterial activity of lemongrass (Cymbopogon citratus) oil against some selected pathogenic bacterias. Asian Pacific $\mathrm{J}$ Trop Med. 2010;3:535-8.

9. Schuck VJA, Fratini M, Rauber CS, Henriques A, Schapoval EES. Evaluation of the antimicrobial activity of Cymbopogon citratus. Rev Bras Ciênc Farm.2001;37:45-9.

10. Carmo ES. Ensaios pré-clínicos e clínicos com óleo essencial de Cymbopogon citratus (DC) Stapf. para tratamento de pitiríase versicolor [tese]. João Pessoa (PB): Universidade Federal da Paraiba, 2011.

11. Mishra AK, Kishore N, Dubey NK, Chansouria JPN. An evaluation of the toxicity of the oils of Cymbopogon citratus and Citrus medica in rats. Phytother Res. 1992;6:279-81.

12. Fandohan P, Gnonlonfin B, Laleye A, Gbenou JD, Darboux R, Moudachirou M. Toxicity and gastric tolerance of essential oils from Cymbopogon citratus, Ocimum gratissimum and Ocimum basilicum in Wistar rats. Food Chem Toxicol. 2008;46:2493-7.

13. Koffi K, Komla S, Catherine G, Christine R, Jean-Pierre C, Laurence N. In vitro cytotoxic activity of Cymbopogon citratus $L$. and Cymbopogon nardus $L$. essential oils from Togo. Bangladesh J Pharmacol. 2009;4:29-34.

14. Bidinotto LT, Costa CA, Salvadori DM, Costa M, Rodrigues MA, Barbisan LF. Protective effects of lemongrass (Cymbopogon citratus STAPF) essential oil on DNA damage and carcinogenesis in female Balb/C mice. J Appl Toxicol. 2010. doi: 10.1002/jat.1593.

15. Al-Waili NS. An alternative treatment for pityriasis versicolor, tinea cruris, tinea corporis and tinea faciei with topical application of honey, olive oil and beeswax mixture: an open pilot study. Complem Therap Med. 2004;12:45-7.

16. Miranda LGA. Identificação de espécies de Malassezia em pacientes com pitiríase versicolor atendidos no ambulatório de dermatologia CAME-primavera em João PessoaPB [dissertação]. Recife (PE): Universidade Federal de Pernambuco; 2004

17. Arenas R, Isa RI, Cruz AC. Pitiriasis versicolor en Santo Domingo, República Dominicana. Datos morfológicos de Malassezia spp. in vivo en 100 casos. Rev Iberoam Micol. 2001;18:29-32.

18. Quintero MEA, Perfetti DJ. Clinical-epidemiological aspects of pytiriasis versicolor (PV) in a fishing community of semiarid region from Falcon State, Venezuela. Rev Iberoam Micol. 2004;21:191-4.

19. Furtado MSS, Cortêz ACA, Ferreira JA. Pityriasis versicolor in Manaus, Amazonas, Brazil. An Bras Dermatol. 1997;72:349-51.
20. Aspiroz C, Ara M, Varea M, Rezusta A, Rubio C. Isolation of Malassezia globosa and M. sympodialis from patients with pityriasis versicolor in Spain. Mycopathologia. 2002;154:111-7.

21. Miranda KC, Araujo CR, Soares AJ, Lemos JA, Hasimoto e Souza LK, Silva MRR Identification of Malassezia species in patients with pityriasis versicolor in Goiânia-GO. Rev Soc Bras Med Trop. 2006;39:582-3.

22. Krisanty RIA, Bramono K, Wisnu IM. Identification of Malassezia species from pityriasis versicolor in Indonesia and its relationship with clinical characteristics. Mycoses. 2008:52:257-2.

23. Pappas PG, Chetchotisakd P, Larsen RA, Manosuthi W, Morris MI, Anekthananon T, et al. A Phase II Randomized Trial of Amphotericin B Alone or Combined with Fluconazole in the Treatment of HIV-Associated Cryptococcal Meningitis. Clin Infect Dis. 2009;48:1775-83.

24. 24. Figueiredo AS. Efeito da farinha desengordurada do Sesamum indicum L. nos níveis glicêmicos e lipídicos de diabéticos tipo 2 [tese]. João Pessoa (PB): Universidade Federal da Paraiba; 2008.

25. Andrade ASBC. Ensaio farmacológico clinico com extrato das raízes do Panax ginseng C.A. Meyer no tratamento da fibromialgia [tese]. João Pessoa (PB): Universidade Federal da Paraiba; 2009.

26. Bristow RG, Hill RP. Comparison between In vitro radiosensitivity and in vivo radioresponse in murine tumor cell lines II: in vivo radioresponse following fractionated treatment and in vitro/in vivo correlations. Int J Radiat Oncol Biol Phys. 1990;18:331-45.

27. Rodriguez-Tudela JL, Alcazar-Fuoli L, Cuesta I, Alastruey-Izquierdo A, Monzon A Mellado $\mathrm{E}$, et al. Clinical relevance of resistance to antifungals. Int J Antimicrobial Agents. 2008, 32: S111-3.

28. Duarte MCT, Figueira GM, Sartoratto A, Rehder VL, Delarmelina C. Anti-Candida activity of brasilian medicinal plants. J Ethnopharmacol. 2005:97:305-11.

29. Nunes XP, Maia GLA, Almeida JRGS, Pereira FO, Lima EO. Antimicrobial activity of the essential oil of Sida cordifolia L. Braz J Pharmacogn. 2006;16:S642-4.

How to cite this article: Carmo ES, Pereira FO, Cavalcante NM, Gayoso CW, Lima EO. Treatment of pityriasis versicolor with topical application of essential oil of Cymbopogon citratus (DC) Stapf - therapeutic pilot study. An Bras Dermatol. 2013;88(3):381-5. 